\title{
REKONTRUKSI HUKUM TRANSAKSI MUAMALAH \\ DENGAN PENDEKATAN KAIDAH FIQHIYYAH
}

\author{
Wartoyo \\ Fakultas Ekonomi Syariah dan Ekonomi Islam \\ IAIN Syekh Nurjati Cirebon \\ Email: wartoyo10@gmail.com
}

\begin{abstract}
Developments and changes in the legal area of muamalah are very dynamic, changes occur not in the number of years or months, but the count of days and even hours. That is why it is required a legal basis that can also offset the rapid change and development that occurs in the muamalat law. Therefore, the scholars of the ushul fiqih have long since laid down the basic rules of ushuliyah and fiqhiyyah rules in order to enable the ulama to be able to easily do the law of istimbath so that a problem in the muamalah clearly the position of the judge. One of the fiqhiyyah rules laid down by ushul fiqh experts is the gift of an au'u minal fardli. According to As-Shuyuti the implementation of this rule is that when faced in an emergency, a matter of sunnah can be interpreted to be broader and more flexible than the law. This paper will try to apply the fiqhiyyah rules when it is implemented in the realm of the muamalah especially in the issues of transactions that develop in today's sharia economic.
\end{abstract}

Keywords: Fiqhiyyah Rules, Muamalah, and Sharia Transaction.

\begin{abstract}
Abstrak
Perkembangan dan perubahan dalam bidang hukum muamalah sangatlah dinamis, perubahan terjadi bukan dalam hitungan tahun atau bulan, melainkan hitungan hari dan bahkan jam. Oleh sebab itulah diperlukan sebuah landasan hukum yang juga dapat mengimbangi cepatnya perubahan dan perkembangan yang terjadi dalam hukum muamalat. Untuk itu para ulama ahli ushul fiqih sejak jauh hari telah meletakkan kaidah-kaidah dasar ushuliyah maupun kaidah fiqhiyyah dengan tujuan agar para ulama sesudahnya dapat dengan mudah melakukan istimbath hukum agar suatu persoalan dalam muamalah jelas kedudukan hukunya. Salah satu kaidah fiqhiyyah yang telah diletakkan oleh para ahli ushul fiqh adalah kadiah an-naflu ausa'u minal fardli. Menurut As-Shuyuti implementasi kaidah ini adalah bahwa bila dihadapkan dalam kondisi darurat, maka suatu perkara sunnah bisa dimaknai lebih luas dan fleksibel hukumnya daripada perkara yang fardlu. Makalah ini akan mencoba mengaplikasikan kaidah fiqhiyyah tersebut bila diimplementasikan dalam ranah muamalah khususnya dalam persoalan-persoalan transaksi yang berkembang dalam ekonomi syariah pada masa sekarang ini.
\end{abstract}

Kata Kunci: Kaidah Fiqhiyyah, Muamalah, dan Transaksi Syariah. 


\section{PENDAHULUAN}

Hukum Islam yang bersumber pada AlQur'an dan Hadis, secara garis besar telah memberikan petunjuk secara tegas dan jelas, mengenai beberapa persoalan dalam muamalah seperti; hukum waris, hukum pernikahan, dan keharaman mengkonsumsi riba, khamr, daging babi dan bangkai. Namun diluar masalah yang hukumnya sudah jelas nash-nya tersebut, masih banyak sekali persoalan-persoalan muamalah lain yang memerlukan kepastian hukum, disebabkan oleh perubahan dan perkembangan teknologi informasi di zaman modern sekarang ini, khususnya yang berkaitan dengan ekonomi. Perubahan dan perkembangan zaman tidaklah bisa dikekang, hal ini sangat disadari oleh para Ulama terdahulu, salah satunya dengan adanya kaidah yang menyatakan : Taghayyuri al ahkam bi taghayyuri al azminah wa al-amkinah. Bahwasanya perubahan hukum itu selalu berjalan beriringan dengan perubahan waktu dan tempat.( Rozalinda, 2016 )

Demikian juag perkembangan dunia ekonomi, selalu selaras dengan perkembangan dunia teknologi dan informasi, hal ini mengakibatkan semakin kompleksnya aspek-aspek yang terkait dengan praktik ekonomi yang berkembang di masyarakat saat ini, mulai dari aspek transaksi, metode pembayaran, metode penyerahan barang, klaim garansi dan aspek-aspek lainnya. Realitas ini tentu tidak bisa dinafikan begitu saja, terutama oleh para ahli hukum islam yang harus melakukan kajian, penelitian dan pembahasan mengenai boleh dan tidaknya suatu transaksi pada masa modern sekarang ini. Dengan adanya kepastian hukum, akan menjadikan umat tidak lagi merasa waswas atau khawatir akan halal dan haramnya menggunakan transaksi-transaksi jenis baru tersebut. Contoh dari pengaruh perkembangan teknologi dan informasi terhadap perkembangan transaksi, adalah munculnya model bisnis e-commerce, e- money, online payment, hingga yang paling baru adalah cryptocurrency.

Dalam khasanah keilmuan agama islam, ilmu ushul fiqh menempati kedudukan yang tinggi, sehingga setiap ahli hukum islam (mujtahid) wajib memahami dan menguasai ilmu ushul fiqh dengan baik dan benar. Penguasaan terhadap ilmu ushul fiqih akan menghindarkan kekeliruan para ahli hukum dalam menentapkan hukum suatu fenomena yang tidak terdapat nashnya baik dalam Al-Qur'an maupun hadis (Khallaf, 1996).

Mayoritas ulama klasik maupun kontemporer memandang, bahwa ilmu ushul fiqh merupakan induk dari ilmu-ilmu syariah. As-Syatibi bahkan menganggap bahwa mempelajari dan menguasai ilmu ushul fiqh adalah suatu yang sifatnya dharuri, sebab melalui disiplin ilmu inilah, dapat digali dan ditemukan kandungan dan maksud setiap dalil qathi (Alquran dan Hadis) dan cara mengimplementasikannya dalam kehidupan sehari-hari. (Mufid, 2016) Bahkan Al-Qaradhawi mengatakan, bahwa sesorang bisa saja menjadi ahli fiqih tanpa harus mempelajari semua kitab-kitab fiqih, yang jumlahnya sangat banyak dari berbagai mazhab. Cukup saja baginya mempelajari ilmu ushul fiqh, sehingga bisa melakukan istimbath hukum, yaitu mengeluarkan kesimpulan dari suatu hukum berdasarkan dalil dalil nash, dengan melakukan pengkajian dan penelitian, baik dengan metode ijtihad istimbaty, ijtihad tathbiqy, ijtihad intiqaiy maupun ijtihad isya'i.( AlQaradhawi, 2000 )

Ushul fiqh secara etimologi, terdiri dari dua kata yaitu ushul yang artinya adalah dasar, pondasi atau asas, dan al-fiqh yang artinya adalah pemahaman atau pengetahuan yang mendalam. Jadi ushul fiqh secara kebahasaan memiliki arti dasar dasar pemahaman. Sedangkan secara istilah, Jumhur Ulama mendefinisikan Ilmu ushul fiqih sebagai ilmu tentang; kaidah-kaidah yang membahas tentang metode istimbat hukum, dari sumber atau dalil yang 
terperinci, atau bisa disebut juga dengan ilmu kaidah-kaidah fiqih.( Zuhaili, 1986 )

Sumber-sumber hukum yang menjadi rujukan bagi setiap Mujtahid dalam ijtihadnya telah disepakati oleh sebagian para ulama ada dua, yaitu Alqur'an dan Hadis, dan terdapat beberapa sumber hukum pendukung yang para ulama masih memiliki perbedaan pandangan dalam kehujjahannya seperti Ijma', Qiyas dan Istihsan, Istishab, maslahah mursalah, syar'u manqablana dan urf (Zuhaili, 1986).

Sedangkan hukum yang dihasilkan dari sumbernya, itu disebut sebagai fiqh. Maka kedudukan ushul fiqih, dalam hal ini adalah lebih tinggi dari ilmu fiqih. Sebab fiqih merupakan produk dari ilmu ushul fiqh (Azhari, 2015). Dari hasil pemahaman dan pendalaman terhadap ilmu ushul fiqh ini, para ulama ushul fiqh merumuskan kaidahkaidah ushul fiqh (qawaid ushuliyah), yang diambil dari dalil-dalil syara baik dalam Alquran maupun Hadis. Hasilnya, terbentuklah kaidah-kaidah ushul fiqh atau qawaid ushuliyah seperti "al-ashlu fil amri lil wujub"(pada dasarnya kalimat perintah itu adalah menunjukkan suatu kewajiban). Kemudian ada juga kaidah; "al-ashlu fi nahyi lil tahrim" (pada dasarnya kalimat larangan adalah menunjukkan keharaman), dan masih terdapat beberapa kaidah ushuliyah, yang menjadi acuan bagi Mujtahid untuk menyimpulkan suatu kejadian hukum.

Adapun Qawaid Fiqhiyyah, menurut Musthafa Az-Zarqa adalah dasar-dasar hukum fiqh, yang bersifat umum dan ringkas, berbentuk peraturan (undangundang) yang berisi hukum-hukum syara' yang umum, terhadap berbagai kejadian hukum, yang termasuk kedalam ruanglingkup kaidah tersebut.( Az-Zarqa, 1989) Sederhananya, kaidah-kaidah fiqh merupakan kerangka acuan bagi pelaksanaan hukum, sekaligus untuk mengetahui hukum dari perbuatan seorang mukallaf.

Munculnya kaidah fiqh ini, merupakan hasil dari pengamatan dan penarikan kesimpulan, yang diperoleh dari pelaksanaan beberapa hukum fiqh dilapangan, sehingga ditemukan suatu kesamaan sebab, yang mendasari hukum beberapa masalah (Azhari, 2015) Dari kesamaan itulah kemudian dirumuskan suatu kaidah fiqh yang bisa diterapkan pada hukum-hukum fiqh lain dengan sebab yang sama.

Lalu dimana letak perbedaan antara kaidah ushuliyah dengan kaidah fiqhiyyah? Bila dilihat dari sisi redaksionalnya, bagi orang-orang awam yang baru mempelajari ilmu ushul fiqh maupun ilmu fiqh, hampir tidak bisa membedakan mana kaidah ushuliyah dan mana kaidah fiqhiyyah, karena keduanya hampir sama dalam aspek rekdaksional. Dibawah ini akan dijelaskan perbedaan antara kaidah ushuliyah dan kaidah fiqhiyyah :

1. Dari segi objeknya, objek dari kaidah ushuliyah adalah dalil-dalil yang dalam Alquran dan Hadis, sedangkan objek dari kaidah fiqhiyyah, adalah perilaku mukallaf. Kaidah ushuliyah berlaku secara umum, sedangkan kaidah fiqhiyyah hanya berlaku pada sebagian besarnya saja, dimana selalu terdapat pengecualian dalam penerapannya.

2. Kaidah ushuliyah merupakan sarana, untuk melakukan istimbath hukum syara yang bersifat amaliyah. Sedangkan kaidah fiqhiyyah adalah hasil dari penerapan hukum yang bersifat amaliyah tersebut. Dimana kaidah fiqhiyyah adalah kompilasi dari hukum-hukum yang memiliki kesamaan, yang mana ketentuan hukumnya merujuk pada kesamaan sebab (illat) (Dahlan, 2016).

Praktik dari teori penggalian hukum, bisa dijelaskan dalam deskripsi berikut ini : dalam Alqur'an terdapat ayat yang berbunyi "aqiimu as-shalah". Redaksi dari ayat tersebut merupakan kalimat perintah (fi'il amr) untuk melaksanakan shalat, karena berbentuk kalimat perintah, maka shalat tersebut hukumnya wajib. Darimana munculnya kesimpulan bahwa shalat itu 
wajib hukumnya? Yaitu berdasarkan kaidah ushul fiqh yang berbunyi "al-ashlu fil amri lil wujub" (pada dasarnya setiap perintah itu wajib untuk dilaksanakan). Dengan demikian, diketahui bahwa shalat itu hukumnya wajib bagi setiap orang muslim mukallaf dengan tatacara dan ketentuan waktu yang dijelaskan pada dalil-dalil maupun sunnah-sunnah Rasul yang berkaitan dengan shalat.

Namun pada kenyataannya, tidak semua orang muslim dapat melaksanakan shalat sesuai dengan perintah dan ketentuan yang seharusnya, disebabkan oleh berbagai halangan syara', misalnya; karena sakit atau sedang bepergian. Sehingga menghalangi mereka untuk melaksanakan shalat sebagaimana mestinya. Maka untuk menetapkan status hukum orang-orang yang sedang berhalangan ini, diperlukan ijtihad untuk memberikan kepastian hukum pada kasus-kasus semacam ini.

Hasil dari ijtihad para Mujtahid kemudian menyatakan bahwa orang yang sedang sakit atau safar diberikan keringanan kepada orang-orang tersebut untuk melaksanakan shalat sesuai dengan kondisinya masing-masing. Untuk yang sakit bisa shalat sambil berbaring, sedangkan yang bepergian dibolehkan shalat dengan duduk dan menghadap tidak kearah kiblat. Kenapa hal ini dibolehkan? Karena keadaan darurat, dimana kemudian masuknya kaidah fiqhiyyah "al-masaqqah tajlibu taysir" bahwasanya keadaan sulit itu mendatangkan suatu kemudahan. Maka kemudian muncul hukum fiqh dimana boleh shalat sambil berbaring bagi orang sakit dan tidak menghadap kiblat bagi yang bepergian dan hukumnya tetap sah shalatnya (Azhari, 2015).

Kaidah fiqhiyyah sendiri, terdapat pembagian lagi kedalam kaidah kulliyah (universal) dan kaidah kaidah furuiyah (kaidah cabang). Kaidah kulliyah yang masyhur di kalangan ulama terdapat lima kaidah, yaitu :

$$
\text { الامور بمقاصدها }
$$

Segala perkara tergantung dari maksud (tujuan)

$$
\text { اليقين لا يز ال بالسك }
$$

"Suatu keyakinan tidak bisa dihilangkan dengan keragu-raguan".

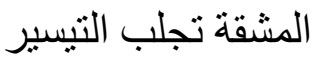

“Kesulitan mendatangakan kemudahan".

$$
\text { الضرار يزا }
$$

"Bahaya (mudharat) harus dihilangkan"

$$
\text { العادة محكمة }
$$

"Adat atau kebiasaan dapat dijadikan pertimbangan menetapkan hukum".

Dari lima kaidah ushuliyah tersebut, masing-masing kaidah kemudian dikembangkan lagi sehingga terbentuk kaidah-kaidah fiqhiyyah lain yang disebut dengan kaidah furu'iyyah atau kaidah cabang. Kaidah furu'iyah yang masyhur dikalangan ulama terdapat kurang lebih 60 kaidah. Dengan rincian, kaidah al-umuru bimaqashidiha memiliki 18 kaidah cabang, kaidah al-yakinu la yuzali bi as-sak memiliki 16 kaidah cabang, al-masaqqatu tajlibu taysir memiliki 8 kaidah cabang, la dharara wa la dhirara memiliki 7 kaidah cabang, dan al-adah muhakkamah memiliki 10 kaidah cabang (Talhah, 2014).

Pada pembahasan kali ini penulis akan menjelaskan mengenai kaidah furuiyah yaitu "an-naflu ausa'u minal fardli" dan implementasinya bila di terapkan dalam pengembangan transaksi-transaksi dan kegiatan ekonomi syariah. Namun sebelum itu akan dijelaskan terlebih dahulu mengenai prinsip-prinsip dasar transaki dalam ekonomi Islam.

\section{METODE PENELITIAN}

Penelitian ini dimaksudkan untuk memahami rekontruksi hukum transaksi muamalah dengan pendekatan kaidah fiqhiyyah. Dalam hal ini peneliti berusaha memahami dan menggambarkan apa yang dipahami dan digambarkan subyek penelitian. Maka penelitian ini menggunakan pendekatan kualitatif dengan metode deskriptif dan jenis penelitian ini 
menggunakan penelitian kepustakaan (library research) yakni penelitian dilaksanakan dengan cara pencarian literatur (kepustakaan) baik berupa buku, catatan, maupun laporan hasil penelitian dari penelitian sebelumnya.

Untuk teknik pengumpulkan data yang diperlukan, penulis melakukannya dengan mengidentifikasi tema dari bukubuku, makalah atau artikel, majalah, jurnal dari hasil penelitian terdahulu, web (internet), atau juga data yang diambil dari informasi lainnya yang berhubungan dengan tema penelitian ini untuk mencari hal-hal atau variable yang berupa catatan, transkip, buku, surat kabar dan sebagainya yang berkaitan dengan kajian tentang rekontruksi hukum transaksi muamalah. Maka dilakukan langkah-langkah sebagai berikut: mengumpulkan data-data yang ada baik dan menganalisa data-data melalui buku-buku teks, dokumen lain, majalah dari web (internet) dan sebagainya.

Dalam penelitian ini setelah mendapatkan beberapa data, maka data tersebut dianalisis untuk mendapatkan kesimpulan, beberapa cara yang terdapat dalam analisa data sebagai berikut: Analisis Deskriptif (Descriptif Analysis), data ini penulis sudah melakukan pemetaan tempat terhadap data-data yang akan dicari diberbagai tempat. Analisis isi (Content Analysis), peneliti mencoba menganalisa lebih dalam berkaitan buku, majalah, jurnal, penelitian bukan hanya isi pada data tersebut melainkan peneliti akan mengungkapkan latar belakang, waktu dan beberapa aspek didalamnya, penulis tersebut mengungkapkan pendapatnya diberbagai data yang terkumpul tersebut.

Analisis data dilakukan secara induktif, yaitu dimulai dari lapangan atau fakta empiris dengan cara terjun ke lapangan, mempelajari fenomena atau fakta empiris dengan cara terjun ke lapangan, mempelajari fenomena yang ada di lapangan. Analisis data dalam penelitian kualitatif dilakukan secara bersamaan dengan cara proses pengumpulan data.
Adapun tahapan analisis data sebagai berikut:

1. Reduksi Data, Hal ini dilakukan dari rekontruksi hukum transaksi muamalah dengan pendekatan kaidah fiqhiyyah secara utuh untuk menarik kesimpulan lebih komprehensif.

2. Penyajian Data, peneliti memberikan kesimpulan rekontruksi hukum transaksi muamalah dengan pendekatan kaidah fiqhiyyah.

3. Pengambilan Keputusan atau Verifikasi, setelah data disajikan, maka dilakukan penarikan kesimpulan atau verifikasi. Untuk itu diusahakan mencari pola, model, tema, hubungan, persamaan, hal-hal yang sering muncul dan sebagainya. Jadi dari data tersebut berusaha diambil kesimpulan. Teknik ini dapat disimpulkan kelebihan dan kekurangan dari rekontruksi hukum transaksi muamalah dengan pendekatan kaidah fiqhiyyah.

\section{PEMBAHASAN DAN DISKUSI}

Ekonomi Islam memiliki tujuan untuk menghantarkan manusia menuju kesejahteraan dunia dan akhirat (falah), dalam usahanya mencapai falah tersebut maka setiap manusia dituntut untuk menggapai maslahah. Kemaslahatan akan tercipta apabila terjadi tercukupinya kebutuhan manusia secara seimbang baik dalam aspek ibadah maupun aspek muamalah (Misanam, et.al., 2013)

Perkembangan dalam dunia ekonomi berjalan begitu pesat, sehingga diperlukan banyak kajian dan penelitian hukum terkait dengan sah atau tidak sah, boleh atau tidak boleh, halal atau haram melakukan kegiatan ekonomi modern tersebut. Bisa dipahami bila ada semacam kevakuman hukum syariah mengenai berbagai hal dan permasalahan dalam dunia ekonomi, hal ini terjadi juga pada sisi hukum positif yang selalu tertinggal dari perkembangan dan kemajuan dunia ekonomi.

Dalam kitab-kitab ushul-fiqh dan figh klasik maupun modern, para ulama 
terdahulu telah banyak meletakkan kaidahkaidah hukum baik ushuliyah muapun fiqhiyyah untuk mengantisipasi terjadinya fenomena-fenomena hukum baru dalam syariah. Kaidah-kaidah ini disusun berdasarkan pengalaman di masa lalu yang terjadi berulang-ulang di berbagai aspek kehidupan. Salah satu kaidah tersebut adalah kaidah yang berbunyi :

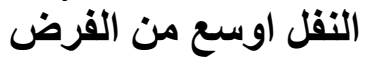

Terjemahan bebas dari kaidah annaflu ausa'u minal fardli : adalah nafl (singular) atau nafilah (jamak) lebih luas cakupannya daripada fardlu atau suatu ketetapan dalam sunnah memiliki jangkauan lebih luas daripada fardlu. Maksud dari kaidah tersebut adalah melaksanakan perbuatan yang dikategorika sebagai perbuatan yang hukumnya sunnah dalam implementasinya di lapangan lebih luas daripada melaksanakan suatu perebuatan yang dikategorikan sebagai perbuatan yang hukumnya fardlu atau wajib (As-Suyuthi, 1997).

Dalam konteks ini, peran fikih tidak dapat dilihat sebelah mata. Ia tetap menjadi faktor determinan yang ikut serta menentukan perjalanan sejarah kemanusiaan umat Islam. Bahkan dalam muamalah, ranah fikih begitu cepat untuk semestinya mengikuti peradaban manusia dalam, misalnya, berbagai bentuk transaksi dengan segala variannya. Ini berbeda dengan wilayah ibadah mahdhah, yang sama sekali tidak diperkenankan mempertanyakan, mengotak-atik atau bahkan melakukan gugatan kritis atasnya (Arifin, 2012).

Dalam penjelasannya As-Suyuti mengatakan bahwa kaidah ini memiliki maksud abhawa melaksanakan suatu perbuatan yang disunnahkan dalam pelaksanaannya lebih luas daripada melaksanakan suatu perbuatan yang hukumnya wajib atau fardlu. Adapun implikasi dari penerapan kaidah ini dalam aspek ibadah adalah sebagai berikut :

1. Orang yang sedang dalam perjalanan diperkenankan shalat tanpa menghadap kiblat. Rukhsah atau keringanan ini tidak berlaku dalam shalat fardlu dan pada shalat sunnah bagi orang yang tidak dalam kondisi sedang bepergian.

2. Tidak diperbolehkan melakukan satu tayamum untuk mengerjakan beberapa kali shalat fardlu, sedangkan dalam shalat sunnah hal demikian diperbolehkan.

3. Dalam puasa sunnah, boleh melakukan niat setelah terbit fajar, sedangkan dalam puasa fardlu tidak sah hukumnya bila tidak berniat dilakukan setelah terbit fajar.

Sebelum kita lebih jauh melakukan pembahasan terhadap kaidah ini, maka akan lebih baiknya kita mengingat kembali apa perbedaan dari istilah fardlu dan nafl ini. Fardlu dalam istilah hukum Islam diartikan sebagai suatu perbuatan yang bila dilaksanakan akan medapatkan pahala dan bila ditinggalkan akan memperoleh dosa (Dahlan, 2016). Sedangkan naflu atau nafilah dalam khasanah hukum islam bisa diartikan sebagai suatu perbuatan yang bila dikerjakan akan mendapatkan pahala dan bila ditinggalkan tidak berdosa. Dalam kaitan dengan ibadah tentu banyak sekali ibadah ibadah nafilah yang ada dalam ritual sehari-hari seperti shalat sunnah, puasa sunnah dan umroh, haji yang kedua dan selanjutnya dan ibadah-ibadah sunnah yang lainnya.

Sebagaimana kita ketahui bahwa kaidah ushuliyah yang menjadi dasar dari hukum muamalah adalah :

الاصل فى المعاملة الاباحة حتى يدل دليل على تحريمها Pada dasarnya semua hal dalam muamalah adalah boleh, sehingga ada dalil yang melarangnya".

Kaidah furuiyyah an-naflu ausa'u minal fardli secara toeiritis sangat dekat kaitannya dengan dengan kaidah lainnya yang berbunyi :

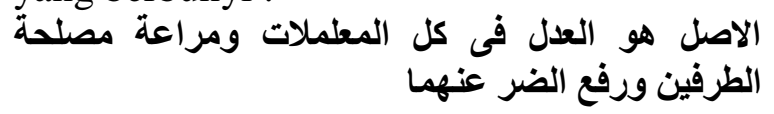

Hukum asal dalam setiap muamalah adalah keadailan, memelihara kemaslahatan dan 
menghilangkan kemudharatan diantara kedua belah pihak.

Kadiah ini menjadi acuan bagi setiap mujtahid untuk melaksanakan aktivitas dan kegiatan dalam muamalah yang intinya adalah berdasarkan pada prinsip keadilan dan kemaslahatan serta menghilangkan kesulitan diantara dua pihak yang sedang bertransaksi. Kedua prinsip ini merupakan kaidah-kaidah yang sangat berguna untuk menyelesaikan bermacam-macam jenis transaski yang muncul dan berkembang di dalam ekonomi syariah yang sesuai dengan maqashid syariah.(Hidayat, 2015)

\section{Transaksi syariah perspektif an-naflu ausa'u minal fardli}

Dalam ruang lingkup fikih muamalah, terdapat juga hal-hal yang dianggap fardlu (wajib) dan juga hal-hal yang dianggap tidak wajib (sunnah). Dalam hal ini kita akan mengambil transaksi jual beli sebagai contoh. Salah satu hal yang sifatnya fardlu atau wajib dalam muamalah secara umum dan transaksi jual beli khsusunya adalah akad. Maka tidak sah hukumnya bila terjadi perpindahan hak atas suatu objek bila tidak melalui akad yang jelas.

Definisi akad secara etimologi adalah perikatan, sedangkan secara terminologi adalah suatu proses perpindahan hak milik dari satu pihak kepada pihak lain menyangkut objek tertentu dengan asas sukarela (Rozalinda, 2017). Akad dari suatu transaksi merupakan hal utama yang harus dipastikan keabsahannya. Sah tidaknya suatu transaksi sangat tergantung dari sah atau tidaknya suatu akad, yang mana di dalam suatu akad terdapat syarat dan rukun yang harus dipenuhi. Maka dari itu bisa kita sebutkan bahwa syarat dan rukun ini adalah hal yang wajib (fardlu) ada dalam setiap akad. Para ulama sepakat bahwa shigat (ijab-qabul) merupakan rukun dari suatu akad. Baik itu akad jual beli, utang piutang maupun sewa menyewa. Perbedaan yang terjadi pada 'aqidain dan ma'qud alaih disebabkan oleh pandangan Mazhab Hanafiyah yang menganggap bahwa kedua hal tersebut merupakan syarat dari sebuah akad, begitu juga sebaliknya jumhur ulama yang menjadikan 'aqidain sebagai rukun dan tidak memasukkannya sebagai syarat dari sebuah akad.

Pada transaksi jual beli online (online shopping) misalnya, antara penjual dan pembeli sangat kecil kemungkinannya untuk melakukan kontak langsung secara fisik, sehingga semua tahapan transaksi dilakukan melalui media online. Penjual memasarkan barang dagangannya hanya dengan memasang gambar-gambar atau katalog di media sosialnya untuk menarik minat pembeli. Bila ada pembeli yang berminat, maka akan terjadi akad ijab dan qabul, dimana ijab qabul disepakati bahkan tanpa adanya pernyataan langsung penyerahan barang dari penjual dan penerimaan qabul dari pembeli secara lisan kedua belah pihak. Selain itu saat ini metode pembayaran yang dilakukan oleh kedua belah pihak tidak lagi dilakukan secara tunai, melainkan melaui transfer atau bahkan dengan menggunakan aplikasi pihak ketiga.

Lalu bagaimana hukumnya? Bila dilihat secara hukum fiqih, maka akan didapatkan banyak hal dalam model transaksi ini yang tidak sesuai dengan hukum fiqih. Pertama terkait shighat yang mana dalam jual beli online tidak jelas shigat ijab qabul yang dilakukan. Kedua terkait dengan 'aqidain atau orang yang bertransaksi, yang mana dalam model jual beli online antara penjual dan pembeli bisa saja masih belum mumayyiz atau bahkan belum baligh. Ketiga, terkait dengan objek transaksi ; objek atau ma'qud alaih tidak berada dalam penguasaan di pedagang, ma'qud alaih masih belum jelas keberadaannya, adanya keraguan ma'qud alaih tidak bisa diserahterimakan, dan adanya kemungkinan terjadinya penipuan baik dari sisi penjual maupun pembeli. Keempat terkait dengan hak khiyar yang diragukan bisa terpenuhi dengan sempurna oleh pembeli, sehingga dikhawatirkan akan 
mengakibatkan perselisihan dan kerugian bagi pembeli.

Secara fiqh, transaksi jual beli tersebut tidak memenuhi syarat dan rukunnya, sehingga hukumnya menjadi tidak sah, namun apabila dikonstruksi dengan mengunakan pendekatan kaidah ushuliyah, maka dapat analisa beberapa hal yaitu pertama, Pada aspek ijab qabul, dalam bisnis online ijab qabul dari 3 (tiga) ketentuan yang menjadi syarat sahnya ijab qabul menurut Jumhur Ulama hanya satu syarat saja yang mungkin tidak dapat terpenuhi secara sempurna, yiatu ijab qabul dilakukan dalam satu majlis secara fisik. Saat ini teknologi informasi sudah sedemikian canggih, sehingga definisi satu majlis bisa nisbatkan kepada chatroom ataupun proses terjadinya komunikasi transaksi melalui media online. Komunikasi secara online dalam bertransaksi melalui media sosial merupakan sebuah kebiasaan baru bagi generasi sekarang ini, maka untuk itu apabila kedua belah pihak telah saling ridha dan syarat-syarat sah pada ma'qud alainya terpenuhi, maka ijab qabulnya menjadi sah. Sebab sahnya persoalan muamalah dikembalikan kepada kebiasaan (al 'urf) (Fauzia dan Riyadi, 2018). Ijab dan qabul tersebut sah berdasarkan pada dalil kebiasaan baik itu berupa ucapan, perbuatan maupun isyarat sehingga tidak mengharuskan dengan suatu ucapan atau perbuatan tertentu. Karena pada dasarnya prinsip muamalah itu tidak adanya persyaratan, dan ketika ada pendapat yang membatasi keabsahan suatu transaksi muamalah dengan mengadakan suatu syarat tertentu, maka hal itu menyalahi prinsip hukum asal (Hidayat, 2015). Dengan demikian, aspek fardlu dalam transaksi hanyalah adanya ijab qabul, Sedangkan yang lainnya merupakan suatu tambahan (nafl) dengan cara dan kebiasaan manusia pada tempat dan waktunya masing-masing.

Kedua, pada aspek 'aqidain atau para pihak yang bertransaksi. Baligh dan mumayyiz merupakan dua unsur pokok syarat sahnya orang yang bertransaksi menurut fiqh. Pada masa sekarang ini konsep baligh dan mumayyiz dengan berpatokan pada umur mungkin sudah tidak relevan untuk diberlakukan lagi, sebab untuk melakukan transaksi jual beli secara online, seseorang benar-benar perlu untuk memahami cara mengoperasikan fitur-fitur yang ada dalam aplikasi jual beli online tersebut. Masalahnya adalah tidak semua orang yang sudah baligh mampu menggunakan dan memahami alur dari transaksi online, oleh sebab itu harus ada perubahan standarisasi baligh dan mumayyiz dalam fiqih sekarang ini, bukan lagi hanya sudah cukup umur tapi juga harus paham dan mengerti benar terkait dengan cara pengoperasian hingga risiko-risiko yang mungkin terjadi dalam transaksi online tersebut.

Ketiga, pada aspek ma'qud alaih terdapat banyak syarat yang harus dipenuhi agar sahnya suatu transaksi. Tidak bisa dipungkiri bahwa dalam bisnis online rentan sekali terjadi penipuan terutama barang yang menjadi onjek transaksi baik itu penipuan secara kualitas maupun kuantitas. Dalam dunia bisnis, terutama perdagangan, keuangan dan jasa hal yang paling utama yang harus selalu dijaga oleh para pelaku bisnis adalah menjada pelayanan dan kepercayaan (trust). Kerika terjadi ketidakpuasan terhadap pelayanan dan ketidakpercayaan karena pernah merasa ditipu, maka bisa dipastikan konsumen tidak akan pernah melakukan transaksi lagi dengan penjual. Pelaku bisnis yang melakukan penipuan secara tidak langsung mematikan sendiri usaha bisnisnya, sehingga lambat laun para pelaku bisnis yang melakukan penipuan akan berkurang dengan sendirinya. Oleh sebab itu, hanya tinggal dari sisi pembeli saja yang harus pandai-pandai memilih merchat penjual bisnis online yang paling bisa dipercaya dan memuaskan dari sisi pelayanan (Fauzia, 2015). Maka dalam hal ini, masalah ma'qud alaih telah terjawab sepenuhnya, baik itu dari kemungkinan adanya penipuan, 
masalah penguasaan terhadap barang dan lainnya.

Keempat, masalah hak khiyar. Pada dasarnya hak khiyar merupakan suatu hukum tambahan atau pelengkap dari syarat dan rukun yang ada dalam jual beli, tujuannya adalah untuk mencapai kemaslahatan kedeua belah pihak yang melakukan transaksi.Pelaksanaan khiyar dalam bisnis online hampir mustahil dilaksanakan karena akan mengakibatkan terjadinya kenaikan ongkos kirim yang mungkin bisa lebih mahal daripada harga barangnya. Namun akhir akhir ini ada juga sebagian reseller/dropshipper yang sudah memberikan fasilitas garansi dalam setiap pembelian produk-produknya. Sehingga bila barang yang datang tidak sesuai dengan yang dipesan, pembeli berhak untuk memutuskan apakah akan meneruskan atau membatalkan transaksi. Oleh karena itu pembeli harus benar-benar selektif dalam memilih reseller yang benar-benar terpercaya dan memberikan garansi terhadap barang yang ditransaksikan.

Tidak dapat dipungkiri bahwa jual beli online ini meliki kelebihan dan kekurangan, kelebihannya antara lain; 1). Menciptakan lapangan kerja baru, 2). Mampu menggerakkan ekonomi sektor riil, 3). Memberikan kemudahan bagi konsumen untuk memilih barang serta dapat membandingkan harga, kualitas dan motif yang sesuai, 4). Membantu para pengusaha kecil dan menengah untuk bisa terus bertahan ditengah persaingan usaha yang ketat, 5). Berkembang pesatnya layanan transaksi online berbasiskan financial technology (Fintech). Sedangkan untuk kekurangnnya antara lain; 1). Rentan terjadinya penipuan yang merugikan salah satu pihak, baik penjual maupun pembeli, 2). Sulitnya penerapan hak khiyar karena faktor jarak, 3). Kemungkinan terjadinya kesalahan (error) dalam proses pembayaran via online (Fauzia, 2015).

Bila dianalisis menggunakan pendekatan kaidah an-naflu ausa'u min alfardli, maka bisa dipastikan jual beli online secara hukum sah adanya. Sebab yang fardlu dalam sebuah transaksi adalah memenuhi 5 prinsip-prinsip dasar transaksi syariah yang telah dijelaskan sebelumnya, yaitu berbuat adil, suka sama suka, tidak zalim, dan objeknya halal. Maka bila sebuah transaksi sudah memenuhi kriteria ini, bisa hukumi transaksi tersebut boleh, karena telah memenuhi prinsip-prinsip dasar transaksi, selain yang lima hal tadi pada prinsipnya adalah tambahan (nafilah). Di atas semua itu pada dasarnya selama transaksi muamalah mampu memerikan maslahah bagi kedua belah pihak, maka secara hukum hal itu dibolehkan dan tidak ada dalil hukum yang melarangnya.

Terkait dengan kemungkinan terjadi penipuan dan kerugian salah satu diantara dua pihak,maka hal itu tidak hanya terjadi dalam bisnis online saja, dalam bisnis kovensional pun pasti terdapat risiko-risiko yang sama, tinggal bagaimana penjual dan pembeli menyikapi hal ini, misalnya dengan memilih penjual (reseller/droshipper) yang terpercaya, memberikan jaminan atau garansi dan ketentuan-ketentuan lain yang dapat meminimalisir risiko yang akan terjadi.

\section{Penerapan Transaksi Pembiayaan di Perbankan Syariah}

Bank syariah adalah lembaga keuangan yang menurut fungsinya berperan sebagai lembaga intermediasi yang melakukan penhimpunan dana dan penyeluran pembiayaan. Dalam penghimpunan dana akad akad yang digunakan adalah wadiah dan mudharabah baik dalam bentuk tabunga, giro dan deposito. Untuk akadakad yang digunakan dalam penghimpunan dana ini, hampir tidak ada masalah, sebab sudah memenuhi aspek-aspek yuridis fiqih yang telah disepakati para ulama. Namun disisi hilir yaitu penyaluran dana atau lebih dikenaldengan istilah pembiayaan, terjadi banyak sekali kesulitan kesulitan yang dihadapi bank dalam implementasinya. Hal ini selain disebabkan oleh SDM bank syariah sendiri yang masih belum mumpuni, 
disebabkan juga oleh nasabah yang selama ini sudah sangat terbiasa melakukan pembiayaan di bank konvensional. Sehingga para nasabah ini menginginkan suatu akad yang sederhana, mudah dipahami dan tidak rumit persyaratannya. Misalnya adalah yang terjadi pada akad salam paralel. Salam adalah akad transaksi jual beli dengan pesanan dengan pembayaran diawal dan barang akan diserahkan kemudian (Mufid, 2015).

Secara sederhana akad salam bisa dideskripsikan sebagai berikut: pengusaha $\mathrm{A}$ memesan barang komoditas ke petani B untuk persediaan barang yang akan dijualnya 3 bulan yang akan datang. Maka terjadilah transaksi antara kedua belah pihak dengan ketentuan pengusaha A membeyar secara tunai harga dari komoditas yang dipesan. Hal dimaksudkan juga agar petani B memiliki modal untuk menanam komoditas yang dipesan pengusaha A. Setelah 3 bulan, maka petani B wajib menyerahkan barang yang dipesan kepada pengusaha A.

Namun pada praktiknya hal ini jarang dipraktikkan, karena mengandur unsur risiko yang besar, baik bagi pembeli maupun penjual. Untuk itu, biasanya penjual akan lebih memilih untuk melakukan transaksi dengan pihak ketiga, dalam hal ini bank syariah dalam hal pemesanan barang yang diinginkan. Maka terjadilah jual beli salam paralel, dimana tidak hanya dua pihak yang terlibat transaksi, namun ditambah satu pihak lagi yaitu bank syariah sebagai pihak ketiga.

Lalu apa untungnya pembeli melakukan transaksi dengan bank? Sedangkan bank bukanlah pihak yang memiliki barang, dan juga bukan pihak yang secara langsung mampu menyediakan yang dimaksud. Keuntungannya adalah, bahwa pembeli bisa melakukan hedging atau lindung nilai terhadap barang yang dipesannya. Selain itu, dengan bertransaksi dengan bank, maka risiko kerugian bisa dikurangi dibandingkan dengan bertransaksi secara langsung dengan pemasok. Bila dideskripsikan adalah sebagai berikut: pengusaha A memesan sebanyak 10 ton barang/komoditas ke bank syariah seharga Rp. $10.000 / \mathrm{kg}$ dengan perjanjian barang harus diterima pada jangka waktu 3 bulan. Pemesan langsung membayar tunai pada saat itu juga. Dalam hal ini bank berposisi sebagai penjual, meskipun barang yang ditransaksikan belum ada. Kemudian bank syariah segera mencari pemasok yang sanggup memenuhi pesanan dari pembeli. Misalkan bank melakukan pesanan barang komoditas tersebut kepada koperasi petani $\mathrm{C}$, dengan perjanjian barang tersebut harus sesuai kualitas dan kuantitasnya dengan keinginan pembeli pertama. Dari hasil tawar menawar, disepakati bank akan membeli komoditas dari keperasi petani sebesar Rp. 8000/kg. Maka singkatnya setelah tiga bulan maka petani harus menyerahkan hasil nya kepada bank, kemudian bank langsung menyerahkannya kepada pembeli pertama.

Selain itu, dengan adanya model transaksi salam paralel ini, akan memberikan keuntungan bagi semua pihak. Pembeli diuntungkan dengan kepastian pengiriman barang tepat waktu dan sesuai dengan kualitas yang diharapkan, selian itu masih ada satu keuntungan lagi yaitu terlindunginya nilai harga dari barang bila sedianya terjadi kenaikan harga komoditas tersebut pada waktu pengiriman. Pihak bank syariah juga memperoleh keuntungan dari hasil selisih harga jual dari pembeli ke pemasok, tentu ini merupakan salah satu akad yang memiliki prospek bagus bila bisa diterapkan secara konsisten. Pemasok, dalam hal ini petani memiliki keuntungan adanya kepastian harga jual dari produk yang dihasilkannya, selain itu juga petani memiliki modal untuk melakukan usahanya dalam rangka memenuhi pesanan, karena pembayaran dilakukan diawal transaksi. Hal yang sama bisa terjadi pada transaksi pembiayaan jual beli istishna dan juga jual beli murabahah dengan pesanan. 


\section{KESIMPULAN}

Ilmu ushul fiqh dan qawaid fiqhiyyah merupakan ilmu yang sangat penting dalam posisinya sebagai dasar acuan bagi para mujtahid dalam melakukan istimbath hukum suatu perkara yang baru. Ilmu ushul fiqh dan qaawaid fiqhiyyah memiliki fleksibilitas dan keluasan cakupan dalam mengakomodir hampir semua bentuk fenomena dan gejala yang timbul di dalam masyarakat. Hukum muamalah sebagai hukum yang terus berkembang seiring dengan berkembangnya zaman, diperlukan usaha penggalian hukum terus menerus agar dapat menjawab semua persoalan yang muncul dalam aspek muamalah. Hal ini sesuai dengan kadiah dasar dari hukum muamalah yaitu pada dasarnya segala bentuk muamalah adalah boleh, sampai ada dalil yang menyatakan keharamannya. Dari kaidah ushul fiqh dapat dipahami bahwa cakupan fiqh muamalah lebih luas dan lebih fleksibel, sehingga setiap kali terjadi perubahan ataupun muncul fenomena baru dapat secara cepat direspon dan dikaji hukumnya oleh para mujtahid.

Tujuan utama dari ekonomi islam adalah mencapai falah dengan jalan mendapatkan maslahah. Maslahah adalah suatu kebaikan yang diperoleh dan dirasakan bersama oleh semua orang. Untuk mencapai kemaslahatan dalam transaksi syariah, para pelaku harus berpegang teguh pada 5 prinsip dasar transaksi ekonomi syariah, yaitu berbuat adil, didasari suka rela, objek transaksinya halal, dan tidak berbuat dzalim. Kaidah an-naflu ausa'u minal fardli bila diterapkan dalam transaksi ekonomi islam dapat diartiken bahwa semua transaksi yang dilakukan dalam ekonomi syariah hukumnya adalah boleh, baik dan dianjurkan, asalkan masih dalam koridor 5 prinsip dasar transaksi yang telah dijelaskan sebelumnya. Misalnya contoh dari penerapannya adalah pada transaksi jual beli online, yang bila dilihat secara fikih tidak memenuhi syarat dan rukunnya. Namun ketika dilakukan dengan pendekatan kaidah ini, bisa menjadi jalan keluar hukum yang sangat baik dan memudahkan bagi umat, sehingga tidak lagi ragu akan hukum-hukum transaksi yang sedang trend pada masa kini.

\section{DAFTAR PUSTAKA}

Arifin, Sirajul. "Musyarakah: Antara Fiqih dan Perbankan Syariah", Jurnal Miqot, Vol. 36 No. 2 (2012).

Al-Qaradhawi, Yusuf. Ijtihad Kontemporer Kode Etik dan Berbagai Penyimpangannya. Surabaya: Risalah Gusti, 2000.

As-Suyuthi, Jalaludin Abdurrahman. AlAsybah wa Nadzair fi Qawaidi wa Furu'i Fiqhi Syafi'iyyah. Riyadh: Maktabah Nazirul Baaz, 1997.

Azhari, Fathurrahman. Qawaid Fiqhiyyah Muamalah. Banjarmasin: LPKU, 2015.

Az-Zarqa, Musthafa. Syarh al-Qawaid alFiqhiyyah. Damaskus: Darul Qolam, 1989.

Fauzia, Ika Yunia. "Akad Wakalah dan Samsarah Sebagai Solusi atau Klaim Keharaman Dropship Dalam Jual Beli Online", Jurnal Islamica, Vol. 9 No. 1 (2015).

Fauzia, Ika Yunia \& Abdul Kadir Riyadi. Prinsip Dasar Ekonomi Islam Perspektif Maqashid Syariah. Jakarta: Penerbit Kencana, 2018.

Hidayat, Enang. 2015. Fiqih Jual Beli. Bandung: Remaja Rosda Karya

Khallaf, Abdul Wahab. Ilmu Ushul Fiqh. Jakarta: Rajawali Press, 1996.

Mardani. Hukum Sistem Ekonomi Islam. Jakarta: Rajawali Press, 2015.

Misanam, Munrokhim, et.al. Ekonomi Islam. Jakarta: Rajawali Press, 2013.

Mufid, Mohammad. Ushul Fiqh Ekonomi dan Keuangan Kontemporer. Jakarta: Penerbit Kencana, 2016.

Rozalinda. Fiqih Ekomoni Syariah; Prinsip dan Implementasinya pada Sektor Keuangan Syariah. Jakarta: Rajawali Press, 2016. 
Sidlan, Shaleh bin Ghanim, Al-Qawaid al Fiqhiyyah al-Kubra wa ma Tafaara'anha. Riyadh: Dar al Nasyri wa al Tauzi',t.th.

Talhah. "Kaidah Fiqhiyyah Furuiyyah; Penerapannya Pada Isu Kontemporer", Jurnal Tahkim, Vol. X No. 1, (2014).

Thalib, Prawitra. "Pengaplikasian Qawaid Fiqhiyyah dalam Hukum Islam Kontemporer", Jurnal Yuridika, Vol. 31 No 1 (2016).

Zuhaili, Wahbah. Ushul Figh al-Islami. Beirut: Dar al-Fikr, 1986. 